\title{
A Comparison Between Swedish Midwives and Obstetricians and Gynecologists Opinions on Cesarean Section
}

\author{
Ann Josefsson, Christina Gunnervik, Adam Sydsjö and Gunilla Sydsjö
}

\section{Linköping University Post Print}

N.B.: When citing this work, cite the original article.

The original publication is available at www.springerlink.com:

Ann Josefsson, Christina Gunnervik, Adam Sydsjö and Gunilla Sydsjö, A Comparison

Between Swedish Midwives and Obstetricians and Gynecologists Opinions on Cesarean Section, 2011, MATERNAL AND CHILD HEALTH JOURNAL, (15), 5, 555-560.

http://dx.doi.org/10.1007/s10995-010-0630-7

Copyright: Springer Science Business Media http://www.springerlink.com/

Postprint available at: Linköping University Electronic Press http://urn.kb.se/resolve?urn=urn:nbn:se:liu:diva-69170 
A comparison between Swedish midwives and obstetricians \& gynecologists opinions on cesarean section

Ann Josefsson ${ }^{1}$, Christina Gunnervik C ${ }^{1,2}$ Adam Sydsjö ${ }^{1}$, Gunilla Sydsjö ${ }^{1}$

${ }^{1}$ Division of Obstetrics and Gynaecology, Department of Clinical and Experimental

Medicine, Faculty of Health Sciences, Linköping University, SE-581 85 Linköping, Sweden

${ }^{2}$ Department of Obstetrics and Gynaecology, Värnamo County Hospital

SE-331 85 Värnamo, Sweden

Correspondence:

Professor Gunilla Sydsjö

Division of Obstetrics and Gynaecology

Linköping University

SE- 58185 Linköping

Sweden

Tel: +4613223167

Fax: +4613148156

Email: Gunilla.Sydsjo@lio.se

Short title: Opinions on cesarean section

Word count: 1771 


\section{Abstract}

Objective: To compare Swedish obstetricians/gynecologists and midwives' attitudes and opinions on different aspects of cesarean section (CS).

Method: In total 330 midwives from the south east of Sweden and 1280 Swedish obstetricians/gynecologists were asked to answer a study-specific questionnaire anonymously about their opinions on different issues concerning CS.

Results: The majority of obstetricians/gynecologists and midwives had more than 10 years of experience in their professions (75.2\% vs. $73.6 \%)$. The midwives thought that a reasonable CS rate would be $11.5 \%$ whereas the corresponding figures for the obstetricians/gynecologists was $13.8 \%(\mathrm{p}<0.001)$. There are differences in opinions and attitudes concerning both CS rates and other aspects in connection with CS.

Conclusion: There are evident differences in attitudes towards CS and mode of delivery between midwives and obstetricians/gynecologists. These need to be explored and discussed in relation to state-of-the-art knowledge and should become a part of the curriculum for both groups of professionals both in training as well as on a regular clinical basis.

Keywords: cesarean, maternal request, attitudes, mode of delivery 


\section{Introduction}

The cesarean section (CS) rate has been the subject of debate during the past few years with most of the attention focused on the steep increase. The reasons for this increase are also matters of concern and are under analysis both from a medical and a public perspective since the "women's own choice" or cesarean on "maternal request" is thought to be the major reasons for the increase (1-3). Among the general public there is an agreement that women have the right to choose both on the basis of concern with bodily integrity and because of fear of childbirth (4). However, among professionals there are contradictory opinions $(5,6)$.

For a woman who is to give birth, her health, wellbeing and delivery are managed by different professions at both the antenatal care clinic (ACC) and the hospital. During pregnancy the pregnant woman should be given adequate and balanced information on issues concerning mode of delivery and other health matters related to the delivery. Some studies have shown that there are differences in maternal caregivers opinions' on how they think one should deal with the woman's wishes and also on what might be an acceptable rate of cesarean section $(5,6)$.

In Sweden the ACC's have their own organization with midwives usually not involved in the delivery process. A pregnant woman visits the ACC's midwives for routine checkups 8-10 times during her pregnancy. The midwives in the delivery wards handle the normal delivery on their own but if there are medical complications an obstetrician takes over the responsibility. The obstetricians/gynecologists who work in hospitals are often dealing with both obstetrics and gynecology but characterize themselves mostly as obstetricians or gynecologists depending on their main working field.

In two recent studies we have investigated midwives and obstetricians/gynecologists attitudes on the subject of CS rates, women's own choice of mode of delivery and on the caregivers personal delivery experiences $(7,8)$. The aim of this study was to explore the differences and 
Opinions on cesarean section

similarities between these two professions' concerning opinions on CS rates, attitudes toward different modes of delivery and attitudes toward providing CS on demand. In addition we wanted to explore if gender, age and experience influence the attitudes held. 


\section{Material and methods}

\section{Obstetricians \& Gynecologists}

A register of all obstetricians/gynecologists working in Sweden was used to identify potential participants for the study. In total, this list included 1346 names and addresses. Sixty-six of the letters were returned because the obstetrician/gynecologist had moved abroad, had retired, did not work as an obstetrician/gynecologist or was deceased. In all 1280 obstetricians/ gynecologists received a study specific questionnaire together with a cover letter stating the purpose of the study and a guarantee of confidentiality together with a pre-stamped envelope. After two reminders, a total of 845 obstetricians/ gynecologists (66\%), 517 females and 328 men, returned a completed questionnaire. Of these $332(45 \%)$ stated that their main professional field was gynecology and $185(25 \%)$ stated obstetrics' as their main professional work area and $228(30 \%)$ were working equal proportions in both fields.

For more background data on the participants see Gunnervik et al 2008 (7).

The study was performed during late 2005 .

\section{Midwives}

All midwives in two Swedish counties in the southeast region of Sweden were asked to participate in a study about attitudes and opinions towards mode of delivery. In total, 330 midwives registered as working within these counties at the time of the investigation were invited and received a postal questionnaire. Included with each questionnaire was a cover letter stating the purpose of the study, with a guarantee of confidentiality and a stamped envelop. Two reminders were sent. Two hundred and seventy-eight (84\%) midwives answered and returned the questionnaire. There were 152 (54.9\%) midwives that were working mainly at the delivery ward and consequently 125 midwives who stated that they 
worked at the ACC. For more background data on the participants see Gunnervik et al. 2008

(8). The study was performed in the spring of 2006

\section{Instrument}

The items were drawn from the literature and from clinical experience and formed three subscales. In the first subscale the participants were asked to provide both personal and professional background data. In the following two subscales the participants were asked to answer questions on personal attitudes towards cesarean section related to professional experience, different aspects on mode of delivery in general and hypothetical questions on the mode of delivery they would prefer themselves/or for their partner and finally a hypothetical question on the mode of delivery they would prefer for their own daughter.

We assessed attitudes by asking the respondents to indicate their agreement with items on a 4point Likert scale. Tables 2 and 3 present data for the collapsed categories "Agree" (Strongly agree \& Agree somewhat), and "Disagree" (Disagree strongly \& Disagree somewhat).

\section{Ethics}

The study was approved by the Human Research Ethics Committee, Faculty of Health Sciences, Linköping University.

\section{Statistics}

All analyses were done using the SPSS program 16.0 (SPSS Inc., Chicago, US).

The $\chi^{2}$-test and the Student's t-test was used to compare differences between midwives and obstetricians/gynecologists. Statistical significance was defined as (two-sided) p-values $\leq$ 0.05. In order to test if the results concerning the attitudes towards CS were affected by the participants' age or working experience we performed multiple logistic regression analyses. In these analyses we included profession/working area (i.e. obstetricians/gynecologists and midwives), age $(<50$ years and $\geq 50$ years $)$, working experience $(\leq 10$ years and $>10$ years $)$ and if the caretaker had children of their own (yes, no) as independent categorical variables. 
Opinions on cesarean section

The dependent variables were all variables included in Table 1 and the results are presented in Table 2. 


\section{Results}

Of the 846 obstetricians/gynecologists $75.2 \%$ had worked for more than 10 years in the profession. The corresponding number of midwives who had been in the profession $>10$ years was $73.6 \%(\mathrm{p}=0.596)$. Of the obstetricians/gynecologists, $43.9 \%$ were younger than 50 years, and of the midwives $47.5 \%(\mathrm{p}=0.330)$ were younger than 50 years. All midwives were women and among the obstetricians/and gynecologists $61.1 \%$ were women.

Swedish midwives thought that a reasonable CS rate would be $11.5 \%$ (SD 3.09); the corresponding figure for the obstetricians/gynecologists was $13.8 \%$ (SD 3.14) $(\mathrm{p}<0.001)$. In a comparison between female obstetricians/gynecologists and midwives, the female doctors accepted a higher CS rate than midwives $13.9 \%$ (SD 3.00) compared to $11.5 \%$ (SD 3.09) $(\mathrm{p}=0.000)$. Male obstetricians/gynecologists accepted a higher level of CS than their female colleagues i.e. both midwifes and physicians'; $13.7 \%(\mathrm{SD}=3.36)$ vs. $13.1 \%(\mathrm{SD}=3.22)$ ( $\mathrm{p}=0.028)$. Having children of their own did not influence the opinion on an appropriate level of CS $(\mathrm{p}=0.469)$.

Midwives and obstetricians/gynecologists differed in all personal attitudes regarding CS except for the two statements "A normal vaginal delivery is preferable compared with a CS" and "I think that all breech presentation should go through an external cephalic version", Table 1.

Working experience, working area (midwife or primarily as an obstetrician) experience of having their own children and age do have some influence on midwives' and physicians' attitudes, depending on the statement (Table 2).

In a comparison of physicians and midwives attitudes on the two statements "One should agree to a woman's right to have an elective CS" and "Elective CS is the safest mode of delivery for both mother and the baby", it was found that obstetricians/gynecologists are more likely than midwives to agree with both of these statements (Table 2). 
Opinions on cesarean section

The only statement where the presence of own children had an effect was "I think that all breech-presentations should go through an external cephalic version" (OR=0.428 p=0.008). On the hypothetical questions concerning preferred mode of delivery there is a difference on how to manage different scenarios, where obstetricians have a much more permissive attitude towards CS than midwives on all questions except "normal pregnancy at term" (Table 3). 


\section{Comment}

We found that midwives and obstetricians/gynecologists differ in their attitudes and opinions on the preferred CS rate and also on all other different aspects on CS except for the two statements: "A normal vaginal delivery is preferable compared with a CS" and "I think that all breech presentations should go through an external cephalic version.

A difference was also found in responses to the hypothetical question on a baby's weight and preferred mode of delivery concerning themselves, a partner or a daughter. There are reasons for concern with the findings from this study in that a pregnant woman might become confused if she receives contradictory information. This may in turn lead to insecurity and even to anxiety and fear about the upcoming childbirth. The consequences for the parents-tobe and or the pregnant woman can be a feeling of conflict about whom to trust and also an insecurity about the competence of the medical staff.

Differences in attitudes among caregivers can be one of the reasons for the steep rise in the rate of CS and may also be an explanation for different CS rates in different hospitals within regions or countries depending on policies and on the level of collaboration between the professions and the pregnant woman.

The reason midwives think that the rates are too high could be explained by the fact that they are neither involved with the decisions for a CS nor the surgical procedure itself. There is evidence that obstetricians/gynecologists are more likely to perform a CS in order to eliminate the risk for malpractice litigation or complaints but also because of their medical knowledge and experience on the status of the mother and child that they believe will help them to see to it that delivery will be as safe as possible (9).

Pregnant women in general agree that the woman herself should be the one to decide about the mode of delivery. The majority of pregnant women would at present choose a vaginal delivery (10). In a study which explored women's experiences of decision making about mode 
of delivery after previous CS the results show that the women wanted control over the decision about planned mode of delivery. However, the women were often making the decision without being provided with comprehensive and specific information about possible health risks and benefits (11). Pregnant women and their partners need to be secure in knowing that there is a working alliance between their midwife and obstetrician based on available scientific evidence and that both professions will work together to give each woman a safe and good delivery experience. Differences in attitudes towards mode of delivery need to be explored and discussed in relation to state-of-the-art knowledge and should become a part of the curriculum for both groups of professionals both in training as well as on a regular clinical basis.

\section{Acknowledgements}

This investigation was supported by grants from The Medical Research Council of Southeast Sweden and Futurum - the Academy of Health care, Jonkoping County Council. We thank statistician, MA, Marie Bladh for excellent statistical advice.

Disclosure of interest: None of the authors have any conflict of interest 


\section{References}

1. Habiba M, Kaminski M, Da Fré M, Marsal K, Bleker O, Libero J, Grandjean H, Gratia P, Guaschino S, Heyl W, Taylor D, Cuttini M. Caesarean section on request: a comparison of obstetricians attitudes in eight European countries. Br J Obstet Gynaecol 2006; 113: 647-56.

2. Cotzias CS, Paterson-Brown S, Fisk NM. Obstetricians say yes to maternal request for elective caesarean section: a survey of current opinion. Eur J Obstet Gynecol Reprod Biol 2001; 97: 15-6.

3. Hildingsson I, Radestad I, Rubertsson C, Waldenstrom U. Few women wish to be delivered by caesarean section. Br J Obstet Gynaecol 2002; 109:618-23.

4. Högberg U, Lynö N, Wulff M, Cesarean by Choice? Empirical study of public attitudes. Acta Obstet Gynecol Scand 2008; 87:1301-1308.

5. Reime, B., et al. Do maternity care provider groups have different attitudes towards birth? Br J Obstet Gynaecol 2004; 111: 1388-93.

6. Monari F, Di Mario S, Facchinetti F, Basevi V. Obstetricians' and midwives' attitudes towards caesarean section. Birth 2008; 35:129-35.

7. Gunnervik C, Sydsjö G, Sydsjö A, Selling KE, Josefsson A. Attitudes towards caesarean section in a nationwide sample of obstetricians and gynecologists. Acta Obstet Gynecol Scand. 2008; 87:438-444.

8. Gunnervik C, Josefsson A, Sydsjö A, Sydsjö G. Attitudes towards mode of birth among Swedish midwives. Midwifery. Jul 142008.

9. Fuglenes D, Oian P, Kristiansen IS. Obstetricians' choice of caesarean delivery in ambiguous cases: is it influenced by risk attitude or fear of complaints and litigation? Am J Obstet Gyncol. 2009; 200:48.

10. Pakenham S, Chamberlain SM, Smith GN. Women's view on elective primary caesarean section. J Obstet Gynaecol Can. 2006; 28:1089-94.

11. Emmett CL, Shaw AR, Montgomery AA, Murphy DJ, Diamond Study group. Women's experience of decision making about mode of delivery after a previous caesarean section: the role of health professionals and information about health risks. Br J Obstet Gynaecol 2006:113:1438-45. 
Table 1. A comparison of personal attitudes regarding cesarean section among midwives and obstetricians/gynecologists.

\begin{tabular}{|c|c|c|c|c|}
\hline & & $\begin{array}{l}\text { Midwives } \\
\mathrm{n}(\%)\end{array}$ & $\begin{array}{c}\text { Obstetricians/gynecologists } \\
\mathrm{n}(\%)\end{array}$ & p \\
\hline A normal vaginal delivery is preferable compared with an elective & Agree & $275(99.3)$ & $829(99.4)$ & 0.823 \\
\hline CS & Disagree & $2(0.7)$ & $5(0.6)$ & \\
\hline \multirow[t]{2}{*}{ One should agree to a woman's right to have an elective CS } & Agree & $61(22.3)$ & $238(28.8)$ & 0.037 \\
\hline & Disagree & $212(77.7)$ & $588(71.2)$ & \\
\hline \multirow[t]{2}{*}{ Elective CS is the best choice for a woman with fear of delivery } & Agree & $17(6.2)$ & $102(12.3)$ & 0.004 \\
\hline & Disagree & $258(93.8)$ & $726(87.7)$ & \\
\hline \multirow{2}{*}{ I consider myself more restrictive to $\mathrm{CS}$ than my colleagues } & Agree & $23(8.8)$ & $251(31.3)$ & $<0.001$ \\
\hline & Disagree & $238(91.2)$ & $551(68.7)$ & \\
\hline \multirow[t]{2}{*}{ Elective $\mathrm{CS}$ is as safe as a vaginal delivery for the mother } & Agree & $65(23.6)$ & $303(36.8)$ & $<0.001$ \\
\hline & Disagree & $211(76.4)$ & $523(63.2)$ & \\
\hline \multirow[t]{2}{*}{ Elective CS is as safe as a vaginal delivery for the baby } & Agree & $88(31.8)$ & $440(53.1)$ & $<0.001$ \\
\hline & Disagree & $189(68.2)$ & $389(46.9)$ & \\
\hline \multirow[t]{2}{*}{ Elective CS is the safest mode of delivery for both mother and baby } & Agree & $7(2.5)$ & $44(5.3)$ & 0.057 \\
\hline & Disagree & $269(97.5)$ & 784 (94.7) & \\
\hline \multirow[t]{2}{*}{ A vaginal delivery increases the risk for incontinence } & Agree & $7(2.5)$ & 105 (12.6) & $<0.001$ \\
\hline & Disagree & $268(97.5)$ & 728 (87.4) & \\
\hline \multirow[t]{2}{*}{ A vaginal delivery increases the risk for prolapse } & Agree & $10(3.6)$ & $104(12.5)$ & $<0.001$ \\
\hline & Disagree & 266 (96.4) & 729 (87.5) & \\
\hline \multirow[t]{2}{*}{ A vaginal delivery increases the risk for pelvic floor insufficiency } & Agree & $13(4.7)$ & 77 (9.2) & 0.018 \\
\hline & Disagree & $261(95.3)$ & $756(90.8)$ & \\
\hline \multirow[t]{2}{*}{ Women's concern about perineal injury has increased the CS rate } & Agree & 54 (19.9) & $226(27.9)$ & 0.009 \\
\hline & Disagree & 217 (80.1) & $584(72.1)$ & \\
\hline \multirow{4}{*}{$\begin{array}{l}\text { I think that an epidural anesthesia increases the risk for fetal } \\
\text { malrotation } \\
\text { I think that all breech-presentations should be delivered with a CS }\end{array}$} & Agree & 31 (11.9) & $51(6.3)$ & 0.003 \\
\hline & Disagree & $230(88.1)$ & 764 (93.7) & \\
\hline & Agree & $130(47.8)$ & $551(66.6)$ & $<0.001$ \\
\hline & Disagree & $142(52.2)$ & 277 (33.4) & \\
\hline \multirow{2}{*}{$\begin{array}{l}\text { I think that all breech-presentations should go through an external } \\
\text { cephalic version }\end{array}$} & Agree & 263 (95.3) & 769 (92.7) & 0.128 \\
\hline & Disagree & $13(4.7)$ & $61(7.3)$ & \\
\hline
\end{tabular}

${ }^{*}$ p-value for $\chi^{2}$-test. 
Table 2. Odds ratios from multivariate logistic regressions with personal attitudes regarding cesarean section as dependent variables and age, working experience, working area and child indicator as independent variables.

\begin{tabular}{|c|c|c|c|c|c|c|c|c|}
\hline & $\begin{array}{c}\text { Experience }^{1} \\
\text { Odds ratio } \\
\text { (CI odds ratio) } \\
\end{array}$ & p & $\begin{array}{c}\text { Odds ratio } \\
\text { (CI odds ratio) }\end{array}$ & $\mathbf{p}$ & $\begin{array}{c}\text { Midwives/ } \\
\text { Obstetricians/ } \\
\text { gynecologists } \\
\text { Odds ratio } \\
\text { (CI odds ratio) } \\
\end{array}$ & $\mathbf{p}$ & $\begin{array}{l}\text { Odds ratio } \\
\text { (CI odds ratio) }\end{array}$ & p \\
\hline $\begin{array}{l}\text { A normal vaginal delivery is preferable } \\
\text { compared with an elective CS }\end{array}$ & $\begin{array}{c}0.453 \\
(0.043-4.781)\end{array}$ & 0.510 & $\begin{array}{c}1.297 \\
(0.244-6.894)\end{array}$ & 0.760 & $\begin{array}{c}1.226 \\
(0.236-6.378)\end{array}$ & 0.809 & $\begin{array}{c}1.073 \mathrm{E} 7 \\
(0.000-.)\end{array}$ & 0.996 \\
\hline $\begin{array}{l}\text { One should agree to a woman's right to have an } \\
\text { elective CS }\end{array}$ & $\begin{array}{c}1.133 \\
(0.764-1.681)\end{array}$ & 0.535 & $\begin{array}{c}1.252 \\
(0.896-1.749)\end{array}$ & 0.188 & $\begin{array}{c}1.421 \\
(1.027-1.967)\end{array}$ & 0.034 & $\begin{array}{c}1.049 \\
(0.687-1.603)\end{array}$ & 0.824 \\
\hline $\begin{array}{l}\text { Elective CS is the best choice for a woman with } \\
\text { fear of delivery }\end{array}$ & $\begin{array}{c}0.671 \\
(0.364-1.236)\end{array}$ & 0.201 & $\begin{array}{c}2.047 \\
(1.193-3.510)\end{array}$ & 0.009 & $\begin{array}{c}2.063 \\
(1.208-3.524)\end{array}$ & 0.008 & $\begin{array}{c}0.810 \\
(0.419-1.565\end{array}$ & 0.531 \\
\hline $\begin{array}{l}\text { I consider myself more restrictive to } \mathrm{CS} \text { than my } \\
\text { colleagues }\end{array}$ & $\begin{array}{c}1.989 \\
(1.288-3.071)\end{array}$ & 0.002 & $\begin{array}{c}1.084 \\
(0.766-1.533)\end{array}$ & 0.649 & $\begin{array}{c}4.959 \\
(3.111-7.886)\end{array}$ & $<0.001$ & $\begin{array}{c}1.063 \\
(0.669-1.690)\end{array}$ & 0.795 \\
\hline $\begin{array}{l}\text { Elective CS is as safe as a vaginal delivery for } \\
\text { the mother }\end{array}$ & $\begin{array}{c}1.147 \\
(0.782-1.680)\end{array}$ & 0.483 & $\begin{array}{c}1.591 \\
(1.152-2.197)\end{array}$ & 0.005 & $\begin{array}{c}1.908 \\
(1.389-2.622)\end{array}$ & $<0.001$ & $\begin{array}{c}1.210 \\
(0.808-1.811)\end{array}$ & 0.356 \\
\hline $\begin{array}{l}\text { Elective CS is as safe as a vaginal delivery for } \\
\text { the baby }\end{array}$ & $\begin{array}{c}0.754 \\
(0.532-1.070)\end{array}$ & 0.113 & $\begin{array}{c}1.705 \\
(1.257-2.312)\end{array}$ & 0.001 & $\begin{array}{c}2.483 \\
(1.855-3.323)\end{array}$ & $<0.001$ & $\begin{array}{c}1.102 \\
(0.748-1.624)\end{array}$ & 0.624 \\
\hline $\begin{array}{l}\text { Elective CS is the safest mode of delivery for } \\
\text { both mother and baby }\end{array}$ & $\begin{array}{c}0.704 \\
(0.259-1.915)\end{array}$ & 0.492 & $\begin{array}{c}2.833 \\
(1.182-6.790)\end{array}$ & 0.020 & $\begin{array}{c}2.419 \\
(1.016-5.760)\end{array}$ & 0.046 & $\begin{array}{c}0.978 \\
(0.376-2.546)\end{array}$ & 0.964 \\
\hline $\begin{array}{l}\text { A vaginal delivery increases the risk for } \\
\text { incontinence }\end{array}$ & $\begin{array}{c}0.631 \\
(0.364-1.093)\end{array}$ & 0.100 & $\begin{array}{c}0.847 \\
(0.505-1.421)\end{array}$ & 0.530 & $\begin{array}{c}6.481 \\
(2.808-14.959)\end{array}$ & $<0.001$ & $\begin{array}{c}1.382 \\
(0.778-2.454)\end{array}$ & 0.270 \\
\hline $\begin{array}{l}\text { A vaginal delivery increases the risk for } \\
\text { prolapse }\end{array}$ & $\begin{array}{c}0.595 \\
(0.349-1.014)\end{array}$ & 0.056 & $\begin{array}{c}0.786 \\
(0.472-1.308)\end{array}$ & 0.354 & $\begin{array}{c}4.321 \\
(2.151-8.683)\end{array}$ & $<0.001$ & $\begin{array}{c}1.094 \\
(0.602-1.988)\end{array}$ & 0.767 \\
\hline $\begin{array}{l}\text { A vaginal delivery increases the risk for pelvic } \\
\text { floor insufficiency }\end{array}$ & $\begin{array}{c}0.772 \\
(0.427-1.394)\end{array}$ & 0.390 & $\begin{array}{c}0.795 \\
(0.459-1.378)\end{array}$ & 0.413 & $\begin{array}{c}2.226 \\
(1.191-4.163)\end{array}$ & 0.012 & $\begin{array}{c}1.176 \\
(0.614-2.253)\end{array}$ & 0.625 \\
\hline $\begin{array}{l}\text { Women's concern about perineal injury has } \\
\text { increased the CS rate }\end{array}$ & $\begin{array}{c}1.049 \\
(0.714-1.541)\end{array}$ & 0.807 & $\begin{array}{c}0.826 \\
(0.589-1.158)\end{array}$ & 0.267 & $\begin{array}{c}1.649 \\
(1.174-2.317)\end{array}$ & 0.004 & $\begin{array}{c}1.243 \\
(0.815-1.897)\end{array}$ & 0.312 \\
\hline $\begin{array}{l}\text { I think that an epidural anesthesia increases the } \\
\text { risk for fetal malrotation }\end{array}$ & $\begin{array}{c}2.165 \\
(1.022-4.584)\end{array}$ & 0.044 & $\begin{array}{c}1.164 \\
(0.675-2.005)\end{array}$ & 0.585 & $\begin{array}{c}0.498 \\
(0.309-0.804)\end{array}$ & 0.004 & $\begin{array}{c}1.094 \\
(0.526-2.273)\end{array}$ & 0.810 \\
\hline $\begin{array}{l}\text { I think that all breech-presentations should be } \\
\text { delivered with a CS }\end{array}$ & $\begin{array}{c}0.723 \\
(0.509-1.027)\end{array}$ & 0.070 & $\begin{array}{c}1.500 \\
(1.106-2.034)\end{array}$ & 0.009 & $\begin{array}{c}2.184 \\
(1.649-2.893)\end{array}$ & $<0.001$ & $\begin{array}{c}1.003 \\
(0.673-1.493)\end{array}$ & 0.989 \\
\hline $\begin{array}{l}\text { I think that all breech-presentations should go } \\
\text { through an external cephalic version }\end{array}$ & $\begin{array}{c}0.436 \\
(0.196-0.970)\end{array}$ & 0.042 & $\begin{array}{c}0.921 \\
(0.517-1.643)\end{array}$ & 0.781 & $\begin{array}{c}0.574 \\
(0.303-1.089)\end{array}$ & 0.089 & $\begin{array}{c}0.428 \\
(0.228-0.803)\end{array}$ & 0.008 \\
\hline
\end{tabular}

1 Reference level= over 10 years

2 Reference level= older than or equal to 50 years of age 
3. Reference level=obstetricians/gyneacologists

4. Reference level $=$ no children

Table 3. Hypothetical questions on preferred mode of delivery due to different scenarios.

\begin{tabular}{|c|c|c|c|c|c|c|}
\hline $\begin{array}{l}\text { I would prefer my self or my partner to be } \\
\text { deliver in the following manner due to the } \\
\text { conditions described: }\end{array}$ & & Obstetricians & Gynecologists & $\begin{array}{c}\text { Midwives at } \\
\text { delivery }\end{array}$ & $\begin{array}{l}\text { Midwives at } \\
\text { ACC }\end{array}$ & $\mathbf{P}^{*}$ \\
\hline \multirow[t]{2}{*}{ Normal pregnancy at term } & Vaginal delivery & 98.5 & 99.3 & 100.0 & 99.1 & 0.426 \\
\hline & $\mathrm{CS}$ & 1.5 & 0.7 & 0.0 & 0.7 & \\
\hline \multirow[t]{2}{*}{ Baby's weight estimated to $4.0-4.4 \mathrm{~kg}$} & Vaginal delivery & 93.9 & 96.8 & 100.0 & 99.3 & 0.002 \\
\hline & $\mathrm{CS}$ & 6.1 & 3.2 & 0.0 & 0.7 & \\
\hline \multirow{2}{*}{ Baby's weight estimated to $4.5-4.9 \mathrm{~kg}$} & Vaginal delivery & 56.7 & 70.8 & 82.5 & 76.6 & $<0.001$ \\
\hline & $\mathrm{CS}$ & 43.3 & 29.2 & 17.5 & 23.4 & \\
\hline \multirow[t]{2}{*}{ Baby's weight estimated to $\geq 5 \mathrm{~kg}$} & Vaginal delivery & 15.7 & 16.9 & 30.9 & 27.0 & 0.001 \\
\hline & $\mathrm{CS}$ & 84.3 & 83.1 & 69.1 & 73.0 & \\
\hline \multirow{2}{*}{$\begin{array}{l}\text { If you have a daughter with a normal pregnancy } \\
\text { at term }\end{array}$} & Vaginal delivery & 99.1 & 99.8 & 100.0 & 100.0 & 0.311 \\
\hline & $\mathrm{CS}$ & 0.9 & 0.2 & 0.0 & 0.0 & \\
\hline \multirow{2}{*}{$\begin{array}{l}\text { I would prefer an elective CS with all breech } \\
\text { presentation. }\end{array}$} & Yes & 69.6 & 64.1 & 42.9 & 52.1 & $<0.001$ \\
\hline & No & 30.4 & 35.9 & 57.1 & 47.9 & \\
\hline
\end{tabular}

p-value for $\chi^{2}$-test. 